\title{
Prevalence of Extended Spectrum Beta Lactamase Producing and Carbapenems Resistance Isolates from Hands of Health Care Workers in a Health Care Setting of Nepal
}

\author{
Binita Koirala Sharma (iD) \\ Department of Microbiology, Gandaki Medical College, Pokhara, Nepal.
}

\begin{abstract}
Background: Hands of healthcare workers (HCWs) could be colonized by potential drug resistant bacteria like Extended Spectrum Beta Lactamase producers (ESBLs) and Carbapenems-resistant (CR) isolates and could become vectors of nosocomial pathogens in healthcare facilities that are associated with an increase of morbidity, mortality and healthcare costs. This study aimed to investigate the prevalence of ESBLs and CR isolates from hands of HCWs with their antibiotic susceptibility pattern. Materials and methods: This was a cross-sectional study that included a total of 150 hand swabs collected from March, 2018 to September, 2018 in Gandaki Medical College and Teaching Hospital. Isolation, identification and antimicrobial susceptibility tests were done using standard microbiological procedures. Results: Among the total isolates of 219 obtained from growth positive samples 92/219(42.01\%) were Gram negative bacteria (GNB) and the most common were Klebsiella spp 32(34.78\%) followed by Escherichia coli 17(18.48\%), Pseudomonas aeruginosa12 (13.04\%), Acenetobacter spp 11(11.96\%), Proteus spp 9(9.78\%), Citrobacter spp 7(7.61\%) and Enterobacter spp 4(4.35\%). The prevalence of ESBLs, CR and ESBLs with Co-resistant to Carbapenems were $19.56 \%, 14.13 \%$ and $9.78 \%$, respectively. The most effective drugs for isolates were Nitrofurantoin followed by Amikacin, Tetracycline and Gentamycin. Distribution pattern of the ESBLs and CR isolates among doctors, nurses, laboratory technicians, helpers and basic science faculties were not significant $(\mathrm{p}>0.05)$. Conclusions: This report revealed the emerging and moderately high prevalence of ESBLs, CR and ESBLs with Co-resistant to Carbapenems GNB with their antibiotic susceptibility patterns found on hands of HCWs in Nepal. Thus, this study could be helpful in developing proper guidelines on hand hygiene and implementation of infection control measures including contact precautions against the spread of infections by such pathogens in healthcare settings.
\end{abstract}

Key Words: Carbapenems-resistance, Extended Spectrum Beta Lactamase producers, Healthcare workers

\section{Corresponding author}

Dr. Binita Koirala Sharma, PhD

Lecturer Department of Microbiology

Gandaki Medical College, Pokhara, Nepal, Tribhuvan University

Mobile no: 00977-9856036122

Email: binita keshab@yahoo.com

Submitted: April 13, 2020

Accepted: June 18, 2020

To cite: Sharma BK. Prevalence of Extended Spectrum Beta Lactamase Producing and Carbapenems Resistance Isolates from Hands of Health Care Workers in a Health Care Setting of Nepal. JGMC Nepal. 2020;13(1):23-31. DOI: 10.3126/igmcn.v13i1.28461

\section{INTRODUCTION}

$\beta$-lactamases are a heterogeneous group of enzymes able to inactivate penicillins, cephalosporins and monobactams. These enzymes, frequently produced by aerobic and anaerobic Gram-negative bacteria, hydrolyze the $\beta$-lactam ring by irreversible hydroxylation, consequently inactivating the antibiotic..$^{1-3}$ Enterobacteriaceae that produce extendedspectrum $\beta$-lactamases carry plasmid-encoded enzymes that can efficiently hydrolyze and confer resistance to a variety of $\beta$-lactam antibiotics. ${ }^{4}$ ESBL-producing organisms are responsible for a significant proportion of infections in health care settings. Treatment of these infections can place an added constraint on already overburdened health systems in developing countries. ${ }^{5}$

Infections with carbapenem-resistant Enterobacteriaceae (CRE) are increasingly being reported from patients in healthcare settings. They are associated with high patient 
morbidity, attributable mortality and hospital costs. The management of infections has been complicated by the emergence of carbapenems resistance pathogens. Carbapenemases are $\beta$-lactamases that hydrolyse carbapenems, usually along with other $\beta$-lactams. ${ }^{6}$ The most frequently occurring species of Enterobacteriaceae which are found to be carbapenem-resistant and that produce carbapenemases, are Klebsiella pneumoniae and Escherichia coli. $^{7}$

Enterobacteriaceae can also produce $\beta$-lactamase enzymes such as AmpCs (chromosomal or acquired) and ESBLs that do not readily inactivate carbapenems on their own but can confer carbapenem resistance when combined with chromosomal porin mutations that prevent accumulation of $\beta$-lactam agents in the bacteria. Finally, the production of carbapenemase enzymes, typically found on mobile genetic elements that inactivate carbapenem and other

$\beta$-lactam antibiotics is increasingly common. ${ }^{8,9}$ These carbapenemase-producing CRE (CP CRE) frequently carry multiple resistance mechanisms, which can include redundant $\beta$-lactamases such as AmpCs and ESBLs and genes conferring resistance to other antimicrobial classes. While Proteus, Providencia, and Morganella species demonstrate intrinsically elevated MICs to Imipenem. ${ }^{10}$ $\beta$-lactams drugs are often the primary therapeutic option for serious infections, and carbapenems in particular areoften considered agents of last resort. Thus, the emergence and spread of ESBLs and carbapenem-resistant Enterobacteriaceae are significant clinical and public health concern.

Hand hygiene before patient contact is strongly recommended by the World Health Organization ${ }^{11}$ and by Hand hygiene guidelines ${ }^{12}$ as a measure to prevent crosstransmission of micro-organisms. Moreover, findings in different studies strongly recommend the implementation of multimodal campaigns to improve Hand hygiene compliance in HCWs and the use of sinkless alternatives such as alcohol based hand rub. ${ }^{12,13}$

HCWs hands might be colonized with ESBLs and carbapenem-resistant Enterobacteriaceae isolates and contaminated hands of healthcare providers may cause threat to not only the life of hospital staffs, patients and visitors but also to the people in the community. Hand hygiene is one of the most important preventive interventions against the spread of infections in healthcare settings. There is a paucity of documented literature on investigation of ESBLs and Carbapenems resistance Gram negative organisms on hands of HCWs from Nepal. To the best of our knowledge this is the first report from Nepal with an exclusive focus on investigating the current prevalence and of ESBL producing, Carbapenems resistance and ESBLs with Co-resistance to Carbapenems Gram negative organisms carriage among hands of HCWs from Nepal. Therefore, the study aimed to investigate the prevalence of ESBLs and CR isolates from hands of HCWs with their antibiotic susceptibility pattern.

\section{MATERIALS AND METHODS}

\section{Study design and setting}

This cross-sectional study was carried out at the Microbiology Laboratory from March, 2018 to September, 2018 after obtaining ethical clearance from Institutional Ethical Committee of Gandaki Medical College and Teaching Hospital. Verbal consent was taken from each participant and all samples were collected after he/she accepted and knew that they were participating in clinical study. The total of 150 hand swab samples were collected from the hands of Health care workers which include doctors, nurses, laboratory technicians and helpers working at various wards and departments of Gandaki Medical College and Teaching Hospital, Prithivichowk, Pokhara, Nepal.

\section{Collection and Processing of Samples}

HCWs working at various wards and departments and basic science faculties of Gandaki Medical College and Teaching Hospital were enrolled in this study who were apparently healthy and not taking any antibiotics two weeks prior to this study. The health care worker's hand swab samples were collected by means of sterile cotton swabs moistened in sterile saline water $(0.85 \%)$. The sterilized cotton buds were rotated onto the overall surface area of palms of both hands and in between of the fingers too. The cotton bud swabs after swabbing the hands were kept in the sterile small tube containing Brain Heart Infusion (BHI) broth separately, labeled and was immediately transported to the microbiology laboratory of Gandaki Medical College and Teaching Hospital (GMC) for further processing.

All the swabs were cultured directly on MacConkey agar, Blood agar and Nutrient agar (Himedia). All cultured plates were incubated aerobically at $37^{\circ} \mathrm{C}$ for 24 hours. Bacterial isolates were identified using standard microbiological techniques. ${ }^{14}$ Antimicrobial susceptibility testing of the isolates was performed by Kirby-Bauer disc diffusion technique and the interpretation was done according to Clinical and Laboratory Standards Institute (CLSI) guidelines (2017). ${ }^{15}$ 


\section{Screening and Confirmation of ESBL}

The ESBL phenotype of identified colonies of Enterobacteriaceae were detected by confirmatory double disk diffusion test according to the CLSI guidelines (2017). ${ }^{15}$ For this, Cefotaxime (30 $\mu \mathrm{g})$ or Ceftazidime (30 $\mu \mathrm{g})$, discs were placed on Mueller-Hinton agar plates, $20 \mathrm{~mm}$ apart (centre to centre) from a Cefotaxime plus Clavulanic acid $(30+10 \mathrm{mcg})$ and ceftazidime plus clavulanic acid $(30+10$ mcg).The zones of inhibition for the Cefotaxime and Ceftazidime alone was compared to that of combined disc of cefotaxime and Cefotaxime plus Clavulanic acid and Ceftazidime plus Clavulanic acid respectively. An increase of $\geq 5 \mathrm{~mm}$ in a zone of inhibition for either antimicrobial agent tested in combination with clavulanate vs zone of the inhibition of the agent when tested alone, was confirmed to be the ESBL producer. Plates were incubated overnight $(18-20 \mathrm{~h})$ at $35^{\circ} \mathrm{C}$.

\section{Carbapenem Susceptibility Testing}

Susceptibility of all the isolates to carbapenems was tested in accordance with the current CLSI guidelines (CLSI 2012).${ }^{16}$ Carbapenem antibiotics Meropenem and Imipenem were used. The discs were placed on the surface of inoculated Mueller Hinton Agar (MHA) (Hi media, India) plates using sterile forceps. The discs were placed about $25 \mathrm{~mm}$ apart, and the plates were incubated for 24 hours at $37^{\circ} \mathrm{C}$ after which zones of inhibition in diameter were recorded according to CDC guidelines (CDC 2009). ${ }^{17}$ Isolates that showed a zone of inhibition $<21 \mathrm{~mm}$ in diameter for Meropenem or $<23 \mathrm{~mm}$ in diameter for Imipenem were considered as carbapenem resistant (CDC 2009). ${ }^{17}$

\section{Data Analysis}

All the data were entered into a computer database using standard format, checked for errors and verified. Data maintained in the computer sheets were organized and analyzed by using GraphPad Prism software for Windows (version 8). A value of $\mathrm{p} \leq 0.05$ was assumed wherever applicable and $95 \%$ confidence intervals along with the exact p-values were presented. Data were presented in appropriate table, figures by calculating percentage, rate etc. Appropriate statistics were applied wherever applicable.

\section{RESULTS}

The total of 150 hand swab samples were collected from the hands of health care workers which include doctors $33.33 \%$ (50/150), nurses 33.33\% (50/150), helpers $13.33 \%$ (20/150), laboratory technicians 6.66\% (10/150) working at various wards and departments of hospital and
13.33\% (20/150) from hands of basic science faculties working at basic science blocks, Rithhepani Lekhnath Pokhara who does not have regular exposure to hospital environment of Gandaki Medical College and Teaching Hospital.

The frequency of bacterial growth positive among the cultivated hand swabs were 60\% (90/150) and $40 \%$ $(60 / 150)$ hand swab samples didn't show any growth. In most of the positive samples, they showed polymicrobial growth. Among the total isolates of 219 obtained from overall growth positive samples in this study 92/219 (42.01\%) isolates were Gram negative bacteria and $127 / 219$ (57.99\%) were Gram positive bacteria. Bacterial isolates were identified using standard microbiological techniques.

\section{Distribution Pattern of Gram-Negative Bacteria Isolated From Hand Swab Samples}

The total numbers of Gram-negative bacteria isolated in this study was 92 isolates from 90 positive hand swab samples. The most common Gram-negative organism isolated in this study were Klebsiella spp 32 (34.78\%) followed by Escherichia coli 17 (18.48\%), Pseudomonas aeruginosa 12 (13.04\%), Acenetobacter spp 11 (11.96\%), Proteus spp 9 (9.78\%), Citrobacter spp 7 (7.61\%) and Enterobacter spp 4 (4.35\%) (Table 1, figure 1$)$.

Table 1. Distibution of Gram-negative bacteria isolated from various hand swab samples.

\begin{tabular}{lcc}
\hline Organism Identified & Number & Frequency \\
Klebsiella spp & 32 & $34.78 \%$ \\
Escherichia coli & 17 & $18.48 \%$ \\
Pseudomonas aeruginosa & 12 & $13.04 \%$ \\
Acenetobacter spp & 11 & $11.96 \%$ \\
Proteus spp & 9 & $9.78 \%$ \\
Citrobacter spp & 7 & $7.61 \%$ \\
Enterobacter spp & 4 & $4.35 \%$ \\
Total & 92 & $100 \%$ \\
\hline
\end{tabular}

\section{Distribution Pattern of ESBLs Isolated Gram Negative Bacteria}

Out of total 92 Gram negative isolates, 18 were found to be ESBLs. The overall prevalence of ESBLs in this study was (18/92) 19.56\%. Out of total isolates Klebsiella spp 6/92(6.52\%); Escherichia coli, 4/92(4.35\%); Pseudomonasaeruginosa 3/92 (3.26\%); Acenetobacter spp 3/92 (3.26\%) and Proteus spp 2/92 (2.17\%) were found to be Extended B-Lactamase Producers. None of the isolated Citrobacter spp and Enterobacter spp was found to ESBLs producers (Table 2 , figure 1 ). 
Table 2. Distribution of ESBLs among the isolated Gram negative bacteria

\begin{tabular}{lcc}
\hline Organism & Number of Isolates Tested & $\begin{array}{c}\text { ESBL Producer } \\
\text { N (\%) }\end{array}$ \\
\hline Klebsiella spp & 32 & $6(6.52 \%)$ \\
Escherichia coli & 17 & $4(4.35 \%)$ \\
Pseudomonas aeruginosa & 12 & $3(3.26 \%)$ \\
Acenetobacter spp & 11 & $3(3.26 \%)$ \\
Proteus spp & 9 & $2(2.17 \%)$ \\
Citrobacter spp & 7 & - \\
Enterobacter spp & 4 & - \\
Total & 92 & $18(19.56 \%)$ \\
\hline
\end{tabular}

\section{Distribution Pattern of Resistance among the Isolated} Gram Negative Bacteria to Carbapenems

Out of total 92 Gram negative isolates, 12 were found to be Carbapenems resistance (Resistant to both Meropenem and Imipenem). The overall prevalence of Carbapenem resistant to both Meropenem and Imipenem in this study was (13/92) 14.13\%. Out of total isolates Klebsiella spp 4/92(4.35\%); Escherichia coli, 3/92 (3.26\%); Pseudomonas aeruginosa 3/92(3.26\%); Acenetobacter spp 2/92 (2.17\%) and Proteus spp 1/92 (1.09\%) were found to be Carbapenems resistant. None of the isolated Citrobacter spp and Enterobacter spp was found to Carbapenems resistant (Table 3 , figure 1 ).

Table 3. Distribution of Resistance among the isolated Gram negative bacteria to carbapenems

\begin{tabular}{|c|c|c|c|c|}
\hline Organism & $\begin{array}{c}\text { Number } \\
\text { of Isolates } \\
\text { Tested }\end{array}$ & $\begin{array}{c}\text { No. resistant } \\
\text { to Meropenem } \\
\text { (Zones<21 mm) } \\
\text { N (\%) }\end{array}$ & $\begin{array}{c}\text { No. resistant } \\
\text { to Imipenem } \\
(\text { Zone<23mm) } \\
\text { N (\%) }\end{array}$ & $\begin{array}{c}\text { No } \\
\text { resistant } \\
\text { to both } \\
\mathrm{N}(\%)\end{array}$ \\
\hline Klebsiella spp & 32 & $4(4.35 \%)$ & $6(6.52 \%)$ & $4(4.35 \%)$ \\
\hline Escherichia coli & 17 & $5(5.43 \%)$ & $3(3.26 \%)$ & $3(3.26 \%)$ \\
\hline $\begin{array}{l}\text { Pseudomonas } \\
\text { aeruginosa }\end{array}$ & 12 & $3(3.26 \%)$ & $3(3.26 \%)$ & $3(3.26 \%)$ \\
\hline $\begin{array}{l}\text { Acenetobacter } \\
\text { spp }\end{array}$ & 11 & $3(3.26 \%)$ & $2(2.17 \%)$ & $2(2.17 \%)$ \\
\hline Proteus spp & 9 & $1(1.09 \%)$ & $1(1.09 \%)$ & $1(1.09 \%)$ \\
\hline Citrobacter spp & 7 & - & - & - \\
\hline $\begin{array}{l}\text { Enterobacter } \\
\text { spp }\end{array}$ & 4 & - & - & - \\
\hline Total & 92 & $16(17.39 \%)$ & $15(16.30 \%)$ & $\begin{array}{c}13 \\
(14.13 \%)\end{array}$ \\
\hline
\end{tabular}

\section{Distribution Pattern ESBLs Producers and Carbapenems Resistance Isolates}

Out of total $92 \mathrm{Gram}$ negative isolates, 9 were found to be ESBLs Producers and Carbapenems resistance. The overall prevalence of ESBLs producers and Co-resistant to Carbapenems in this study was (9/92) 9.78\%. Out of total isolates Klebsiella spp 3/92 (3.26\%); Escherichia coli, 2/92 (2.17\%); Pseudomonas aeruginosa 2/92 (2.17\%); Acenetobacter spp 1/92(1.09\%) and Proteus spp 1/92 (1.09\%) were found to be ESBLs producers and Coresistant to Carbapenems. None of the isolated Citrobacter spp and Enterobacter spp was found to ESBLs producers and Co-resistant to Carbapenems (Table 4).

Table 4. Distribution of ESBLs Producers and Carbapenems Resistance Isolates

\begin{tabular}{lcc}
\hline \multicolumn{1}{c}{ Organism } & $\begin{array}{c}\text { Number of Isolates } \\
\text { Tested }\end{array}$ & $\begin{array}{c}\text { ESBL Producer + } \\
\text { Carbapenems Resistance } \\
\text { N (\%) }\end{array}$ \\
Klebsiella spp & 32 & $3(3.26 \%)$ \\
Escherichia coli & 17 & $2(2.17 \%)$ \\
Pseudomonas aeruginosa & 12 & $2(2.17 \%)$ \\
Acenetobacter spp & 11 & $1(1.09 \%)$ \\
Proteus spp & 9 & $1(1.09 \%)$ \\
Citrobacter spp & 7 & - \\
Enterobacter spp & 4 & - \\
Total & 92 & $9(9.78 \%)$ \\
\hline
\end{tabular}

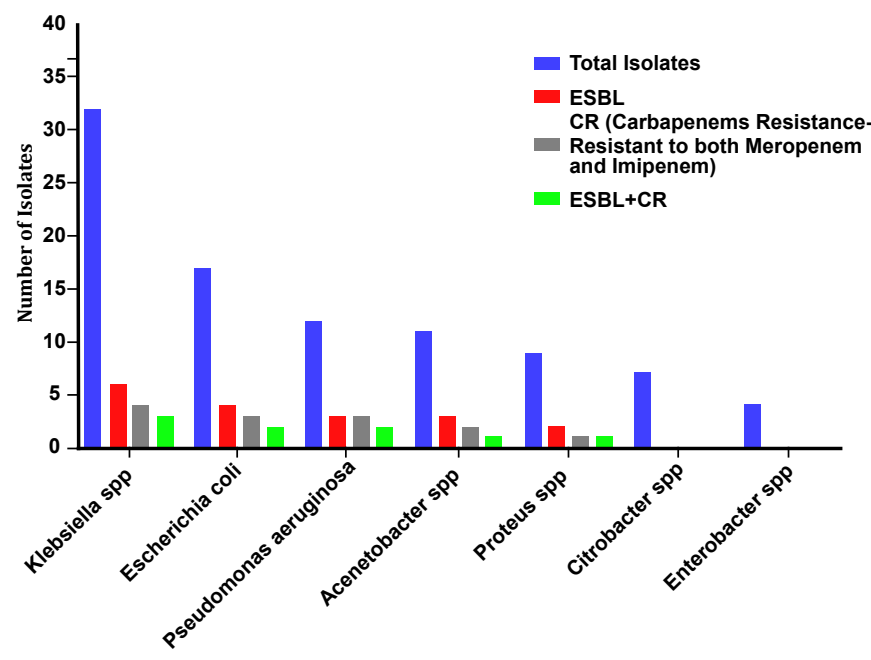

Figure1: Distribution of ESBLs Producers, Carbapenems Resistance and ESBLs producers with Co-resistance to Carbapenems among the isolated Gram negative bacteria.

\section{Antibiotic Susceptibility Test of the isolated Gram-} negative bacteria

Various antibiotics were used for antibiotic susceptibility pattern determination using Kirby Bauer disc diffusion method. The most effective drug of choice for different isolates were Nitrofurantoin followed by Amikacin, Tetracycline and Gentamycin. All the isolates were $100 \%$ resistant to ampicillin and Amoxicillin+Clavulanate. Neither isolates of Citrobacter spp and Enterobacter 
spp obtained in this study were resistant to Cefotaxime, Ceftazidime, Meropenem and Imipenem (Table 5).

Table 5. Antibiotic Susceptibility Test of the Isolated GramNegative Bacteria from Hand Swab Samples

\begin{tabular}{|c|c|c|c|c|c|c|c|}
\hline $\begin{array}{l}\text { Patho- } \\
\text { gens }\end{array}$ & $\begin{array}{c}\text { Kleb- } \\
\text { siella } \\
\text { spp }\end{array}$ & $\begin{array}{c}\text { Esche- } \\
\text { richia } \\
\text { coli }\end{array}$ & $\begin{array}{c}\text { Pseu- } \\
\text { domo- } \\
\text { nas } \\
\text { aerugi- } \\
\text { nosa }\end{array}$ & $\begin{array}{c}\text { Acene- } \\
\text { to- } \\
\text { bacter } \\
\text { spp }\end{array}$ & $\begin{array}{l}\text { Prote- } \\
\text { us spp }\end{array}$ & $\begin{array}{c}\text { Citro- } \\
\text { bacter } \\
\text { spp }\end{array}$ & $\begin{array}{c}\text { En- } \\
\text { tero- } \\
\text { bacter } \\
\text { aero- } \\
\text { gens }\end{array}$ \\
\hline $\begin{array}{c}\text { Total } \\
\text { no. of } \\
\text { isolates }\end{array}$ & 32 & 17 & 12 & 11 & 9 & 7 & 4 \\
\hline \multicolumn{8}{|c|}{ No. of isolates resistant to } \\
\hline CTX & $\begin{array}{c}6 \\
(18.75 \%)\end{array}$ & $\begin{array}{c}4 \\
(23.52 \%)\end{array}$ & $\begin{array}{c}3 \\
(25.0 \%)\end{array}$ & $\begin{array}{c}3 \\
(27.27 \%)\end{array}$ & $\begin{array}{c}2 \\
(22.22 \%)\end{array}$ & 0 & 0 \\
\hline CAZ & $\begin{array}{c}6 \\
(18.75 \%)\end{array}$ & $\begin{array}{c}4 \\
(23.52 \%)\end{array}$ & $\begin{array}{c}3 \\
(25.0 \%)\end{array}$ & $\begin{array}{c}3 \\
(27.27 \%)\end{array}$ & $\begin{array}{c}2 \\
(22.22 \%)\end{array}$ & 0 & 0 \\
\hline MEM & $\begin{array}{c}4 \\
(12.50 \%)\end{array}$ & $\begin{array}{c}5 \\
(29.41 \%)\end{array}$ & $\begin{array}{c}3 \\
(25.0 \%)\end{array}$ & $\begin{array}{c}3 \\
(27.27 \%)\end{array}$ & $\begin{array}{c}1 \\
(11.11 \%)\end{array}$ & 0 & 0 \\
\hline IPM & $\begin{array}{c}6 \\
(18.75 \%)\end{array}$ & $\begin{array}{c}3 \\
(17.64 \%)\end{array}$ & $\begin{array}{c}3 \\
(25.0 \%)\end{array}$ & $\begin{array}{c}2 \\
(18.18 \%)\end{array}$ & $\begin{array}{c}1 \\
(11.11 \%)\end{array}$ & 0 & 0 \\
\hline AMP & 0 & 0 & 0 & 0 & 0 & 0 & 0 \\
\hline AMC & 0 & 0 & 0 & 0 & 0 & 0 & 0 \\
\hline CRO & $\begin{array}{c}26 \\
(81.25 \%)\end{array}$ & $\begin{array}{c}14 \\
(82.35 \%)\end{array}$ & $\begin{array}{c}10 \\
(83.33 \%)\end{array}$ & $\begin{array}{c}10 \\
(90.90 \%)\end{array}$ & $\begin{array}{c}8 \\
(88.88)\end{array}$ & $\begin{array}{c}6 \\
(85.71 \%)\end{array}$ & $\begin{array}{c}3 \\
(75.0 \%)\end{array}$ \\
\hline $\mathrm{NX}$ & $\begin{array}{c}25 \\
(78.12 \%)\end{array}$ & $\begin{array}{c}12 \\
(70.58 \%)\end{array}$ & $\begin{array}{c}9 \\
(75.0 \%)\end{array}$ & $\begin{array}{c}9 \\
(81.81 \%)\end{array}$ & $\begin{array}{c}7 \\
(77.77 \%)\end{array}$ & $\begin{array}{c}5 \\
(71.42 \%)\end{array}$ & $\begin{array}{c}2 \\
(50.0 \%)\end{array}$ \\
\hline GEN & $\begin{array}{c}17 \\
(53.12 \%)\end{array}$ & $\begin{array}{c}7 \\
(41.17 \%)\end{array}$ & $\begin{array}{c}4 \\
(33.33 \%)\end{array}$ & $\begin{array}{c}4 \\
(36.36 \%)\end{array}$ & $\begin{array}{c}4 \\
(44.44 \%)\end{array}$ & $\begin{array}{c}3 \\
(42.85 \%)\end{array}$ & $\begin{array}{c}2 \\
(50.0 \%)\end{array}$ \\
\hline СОТ & $\begin{array}{c}24 \\
(75.0 \%)\end{array}$ & $\begin{array}{c}14 \\
(82.35 \%)\end{array}$ & $\begin{array}{c}8 \\
(66.66 \%)\end{array}$ & $\begin{array}{c}7 \\
(63.63 \%)\end{array}$ & $\begin{array}{c}7 \\
(77.77 \%)\end{array}$ & $\begin{array}{c}6 \\
(85.71 \%)\end{array}$ & $\begin{array}{c}3 \\
(75.0 \%)\end{array}$ \\
\hline $\mathrm{TE}$ & $\begin{array}{c}10 \\
(31.25 \%)\end{array}$ & $\begin{array}{c}6 \\
(35.29 \%)\end{array}$ & $\begin{array}{c}5 \\
(41.66 \%)\end{array}$ & $\begin{array}{c}4 \\
(36.36 \%)\end{array}$ & $\begin{array}{c}3 \\
(33.33 \%)\end{array}$ & $\begin{array}{c}2 \\
(28.57 \%)\end{array}$ & $\begin{array}{c}2 \\
(50.0 \%)\end{array}$ \\
\hline AK & $\begin{array}{c}8 \\
(25.0 \%)\end{array}$ & $\begin{array}{c}5 \\
(29.41 \%)\end{array}$ & $\begin{array}{c}3 \\
(25.0 \%)\end{array}$ & $\begin{array}{c}3 \\
(27.27 \%)\end{array}$ & $\begin{array}{c}2 \\
(22.22 \%)\end{array}$ & $\begin{array}{c}1 \\
(14.28 \%)\end{array}$ & $\begin{array}{c}1 \\
(25.0 \%)\end{array}$ \\
\hline NIT & $\begin{array}{c}3 \\
(9.37 \%)\end{array}$ & $\begin{array}{c}3 \\
(17.64 \%)\end{array}$ & $\begin{array}{c}2 \\
(16.66 \%)\end{array}$ & $\begin{array}{c}2 \\
(18.18 \%)\end{array}$ & $\begin{array}{c}1 \\
(9.09 \%)\end{array}$ & $\begin{array}{c}1 \\
(14.28 \%)\end{array}$ & $\begin{array}{c}1 \\
(25.0 \%)\end{array}$ \\
\hline
\end{tabular}

CTX, Cefotaxime; CAZ, Ceftazidime; MEM, Meropenem; IPM, Imipenem; AMP, Ampicillin; AMC, Amoxicillin+Clavulanate ; CRO, Ceftriaxone; NX, Norfloxacin; GEN, Gentamycin; COT, Cotrimoxzole; TE, Tetracycline; AK, Amikacin; NIT, Nitrofurantoin.

\section{Distribution of Isolates of ESBLs Producers, Carbapenems Resistance and ESBLs producers with Co-resistance to Carbapenems in Relation to Samples Group}

Among the total 92 Gram negative isolates obtained from different study groups total isolates were 18/92 (19.56\%) from doctors, 29/92 (31.52\%) from nurses, 19 (20.65\%) from helpers, 15 (16.30\%) from laboratory technicians and $11(11.96 \%)$ from basic science faculties.Out of those tested 92 isolates $3(3.26 \%)$ from doctors, 6 (6.52\%) from nurses, 3 (3.26\%) from helpers, $4(4.35 \%)$ from laboratory technicians and $2(2.17 \%)$ from basic science faculties that produced ESBLs, Among the 92 isolates tested, 2 $(2.17 \%)$ from doctors, $5(5.43 \%)$ from nurses, $2(2.17 \%)$ from helpers, 3 (3.26\%) from laboratory technicians and $1(1.09 \%)$ from basic science faculties wereresistant to Carbapenems (Resistant to both Meropenem and Imipenem). Out of 92 isolates tested 2(2.17\%) from doctors, 3(3.26\%) from nurses, 1(1.09\%) from helpers, $2(2.17 \%)$ from laboratory technicians and 1 (1.09\%) from basic science faculties were ESBLs producers with Coresistance to Carbapenems. These data were not found in significantly different percentage from different study groups with $\mathrm{p}>0.05$ (ESBLs, $\mathrm{p}=0.37 ; \mathrm{CR}, \mathrm{p}=0.40$; ESBLs+CR, $\mathrm{p}=0.43$ ) (Table 6).

Table 6. Distribution Pattern of Isolates of ESBLs Producers, Carbapenems Resistance and ESBLs producers with Co-resistance to Carbapenems in Relation to Sample Groups

\begin{tabular}{|c|c|c|c|c|c|c|c|}
\hline & $\begin{array}{c}\text { Doctors } \\
\text { N (\%) }\end{array}$ & $\begin{array}{l}\text { Nurses } \\
\text { N (\%) }\end{array}$ & $\begin{array}{c}\text { Helpers } \\
\mathrm{N}(\%)\end{array}$ & $\begin{array}{c}\text { Laboratory } \\
\text { Techncians } \\
\text { N (\%) }\end{array}$ & $\begin{array}{c}\text { Basic } \\
\text { Science } \\
\text { Faculties } \\
\text { N (\%) }\end{array}$ & $\begin{array}{r}\text { Total } \\
\text { N (\%) }\end{array}$ & $\begin{array}{c}\text { “p” } \\
\text { value }\end{array}$ \\
\hline \multicolumn{8}{|c|}{ ESBLs Producers N (\%) } \\
\hline $\begin{array}{l}\text { Total } \\
\text { Isolates } \\
\text { Tested }\end{array}$ & 18 & 29 & 19 & 15 & 11 & 92 & \multirow{2}{*}{0.37} \\
\hline $\begin{array}{l}\text { ESBL } \\
\text { Positive } \\
(\%)\end{array}$ & $\begin{array}{c}3 \\
(3.26)\end{array}$ & $\begin{array}{c}6 \\
(6.52)\end{array}$ & $\begin{array}{c}3 \\
(3.26)\end{array}$ & $\begin{array}{c}4 \\
(4.35)\end{array}$ & $\begin{array}{c}2 \\
(2.17)\end{array}$ & $\begin{array}{c}18 \\
(19.56)\end{array}$ & \\
\hline \multicolumn{8}{|c|}{ Carbapenems Resistance (CR=Resistance to both Meropenem and Imipenem) N (\%) } \\
\hline $\begin{array}{l}\text { Total } \\
\text { Isolates } \\
\text { Tested }\end{array}$ & 18 & 29 & 19 & 15 & 11 & 92 & \multirow{2}{*}{0.40} \\
\hline $\mathrm{CR}$ & $\begin{array}{c}2 \\
(2.17)\end{array}$ & $\begin{array}{c}5 \\
(5.44)\end{array}$ & $\begin{array}{c}2 \\
(2.17)\end{array}$ & $\begin{array}{c}3 \\
(3.26)\end{array}$ & $\begin{array}{c}1 \\
(1.09)\end{array}$ & $\begin{array}{c}13 \\
(14.12)\end{array}$ & \\
\hline \multicolumn{8}{|c|}{ ESBLs+CR (ESBLs Producers with Co-Resistance to Carbapenems) N (\%) } \\
\hline $\begin{array}{l}\text { Total } \\
\text { Isolates } \\
\text { Tested }\end{array}$ & 18 & 29 & 19 & 15 & 11 & 92 & \multirow[t]{2}{*}{0.43} \\
\hline $\mathrm{ESBL}+\mathrm{CR}$ & $\begin{array}{c}2 \\
(2.17)\end{array}$ & $\begin{array}{c}3 \\
(3.26)\end{array}$ & $\begin{array}{c}1 \\
(1.09)\end{array}$ & $\begin{array}{c}2 \\
(2.17)\end{array}$ & $\begin{array}{c}1 \\
(1.09)\end{array}$ & $\begin{array}{c}9 \\
(9.78)\end{array}$ & \\
\hline
\end{tabular}

\section{DISCUSSION}

Hand washing may not usually be performed often enough and many HCWs may not wash their hands properly in the course of their work throughout the day and contaminated hands of healthcare providers play a major role in spreading infections in healthcare settings. The emergence and spread of ESBLs and Carbapenems resistant bacteria through hands of HCWs is a public health threat as they usually associated with an increase of morbidity, mortality and healthcare costs. Hand hygiene is one of the most important preventive interventions against the spread of infections in healthcare settings. 
In this study, the frequency of growth positive for bacteria among the cultivated hand swabs were 60\% (90/150) and $40 \%(60 / 150)$ hand swab samples didn't show any growth. In most of the positive samples, they showed polymicrobial growth. The isolation rate of the pathogens was lower than previous study carried out by Kumari et $\mathrm{l}^{18}$ but comparable with the findings of Vedavati and Halesh ${ }^{19}$. Among the total isolates of 219 obtained from overall growth positive samples in this study 92/219 (42.01\%) isolates were Gram negative bacteria and 127/219 (57.99\%) were Gram positive bacteria. In this study, Gram positive bacteria were found to occur more than Gram negative bacteria. Most skin flora bacteria are Gram positive, which would account for their predominance on hand swab samples which was in accordance with the findings of Vedavati and Halesh ${ }^{19}$ who also demonstrated that the Gram positive bacteria predominate over Gram negative bacteria from the growth positive hand samples.

This study also highlighted the presence of potential pathogenic Gram-negative bacteria in hands of HCWs like Klebsiella spp 32(34.78\%) followed by Escherichia coli 17(18.48\%), Pseudomonas aeruginosa 12(13.04\%), Acenetobacter spp 11(11.96\%), Proteus spp 9(9.78\%), Citrobacter spp 7(7.61\%) and Enterobacter spp 4(4.35\%). Similar types of pathogens were found on hands of health care workers in studies done by Vedabati and Halesh ${ }^{19}$ and Kumari et $\mathrm{al}^{18}$. The presence of these pathogenic bacteria on hands poses a potential risk to vulnerable, immunecompromised individuals. The fact that bacteria of the Enterobacteriaceae found on hands may indicate feacal contamination of the hands.

The overall prevalence of ESBLs in this study was (18/92) $19.56 \%$. The frequency of ESBL producer in other studies was higher than our studies. ${ }^{20,21}$ It may be due to steadily increasing the incidence of ESBL producing strains among the clinical isolates, also the prevalence of ESBLs among clinical isolates varies from country to country and from institution to institution. ${ }^{22}$ In the present study, Klebsiella spp was found to be the most common ESBL producer which was in concordance with the previous studies of Nepal and other countries. ${ }^{23-26}$ who had also reported that Klebsiella spp were the predominant ESBL producers among the clinical isolates. However, another study from Nepal has reported that Escherichia coli were the predominant ESBL producers among the clinical isolates. ${ }^{20}$ In this study, none of the isolates of Citrobacter spp and Enterobacter spp were found to ESBLs positive which was in agreement with the findings of Lohani et $\mathrm{al}^{20}$ who also reported none of the isolates of $C$. freundii were
ESBL positive in their study. It might be because of the less number of isolates. ${ }^{27}$

The overall prevalence of Carbapenem resistant to both Meropenem and Imipenem in this study was (13/92) $14.13 \%$ which was lower as compared to prevalence of Carbapenem resistance from the family Enterobactericeae by Pokhrel et $\mathrm{al}^{28}$. Among which most common bacteria was Klebsiella spp followed by Escherichia coli which was in agreement with the findings of previous studies done in Nepal by Pokhrel et $\mathrm{al}^{28}$ and Bora et $\mathrm{al}^{29}$ among the clinical isolates. None of the isolated Citrobacter spp and Enterobacter spp was found to be resistant to Carbapenems. In this study E. coli was more resistant to Meropenem followed by Klebsiella spp, Pseudomonas aeruginosa, Acenetobecter spp and Proteus spp. While, K. pneumoniae was more resistant to Imipenem followed by E. coli, Pseudomonas aeruginosa, Acenetobacter spp and Proteus spp. Poor hygienic practices by HCWs are some of the driving forces of ESBLs producers and Carbapenems resistance in this study. This is in accordance with the findings of Yusuf et $\mathrm{al}^{30}$ who also demonstrated that E. coli was more resistant to Meropenem than to Imipenem while, in K. pneumoniae, the reverse was the case. The resistant genes in these pathogens could be easily transmitted not only to other HCWs, patients and visitors but also to the community if proper care is not taken.

The most effective drugs of choice for different isolates were Nitrofurantoin followed by Amikacin, Tetracycline and Gentamycin. A comparable finding was obtained by Chander and Shrestha ${ }^{23}$ who also reported Nitrofurantoin and Aminoglycosides as optimal drugs of choice for isolated pathogens. Similarly Pokhrel et $\mathrm{al}^{28}$ reported the increased rate of sensitivity of Amikacin in Carbapenem resistant enterobacteriaceae. All the isolates were 100\% resistant to Ampicillin and Amoxicillin+Clavulanate. Neither isolates of Citrobacters $p p$ and Enterobacter spp obtained in this study were resistant to Cefotaxime, Ceftazidime, Meropenem and Imipenem. The overall prevalence of ESBLs producers and Co-resistant to Carbapenems in this study was (9/92) 9.78\%. Out of total isolates Klebsiellaspp 3/92 (3.26\%); Escherichia coli, 2/92 (2.17\%); Pseudomonas aeruginosa 2/92 (2.17\%); Acenetobacter spp 1/92 (1.09\%) and Proteus spp 1/92 (1.09\%) were found to be ESBLs producers and Coresistant to Carbapenems. None of the isolated Citrobacter spp and Enterobacter spp was found to ESBLs producers and Co-resistant to Carbapenems. Though the prevalence is moderately high in this study, the simultaneous resistance to ESBL and Carbapenems by the isolates in 
hands of HCWs make the whole scenario more alarming. The health care workers harboring the ESBLs and Carbapenems resistant strains might be asymptomatic and could serve as carriers of these strains. Hand hygiene is one of the most important preventive interventions against the spread of infections by such pathogens not only to hospital settings but also to the community

\section{Strengths and limitations}

This study will be a useful reference for future studies, to explore and expand on the wider prevalence of ESBLs, Carbapenems resistant and ESBLs with Co-resistant to Carbapenems Gram negative organism found on hands of health care workers in Nepal. Since our study was based on phenotypic detection of ESBL production and Carbapenem resistance genotypic characterization is recommended in future studies.

\section{CONCLUSION}

The study identified a baseline of data on types of Gram negative bacterial isolates along with their antibiotic susceptibility patterns. This report revealed the emerging and moderately high prevalence of ESBLs, Carbapenems resistant and ESBLs with Co-resistant to Carbapenems Gram negative bacteria found on hands of health care workers in Nepal. Thus, this study could be helpful in developing proper guidelines on hand hygiene and implementation of infection control measures including contact precautions against the spread of infections by such pathogens in healthcare settings.

\section{Conflict of Interest}

The authors declare that they have no competing interests.

\section{Acknowledgments}

The author would like to express deep thanks and sincere appreciation to Dr. Keshab Sharma, Dr Madhu Timilsina and Ms. Sarita Adhikari for their help during sample collection. Authors would like to thank to the Dr. Sanjib Mani Regmi, laboratory technologist Mr. Bashanta Bhujel and all the faculty members of department of Microbiology, Gandaki Medical College and Teaching Hospital for their support.

\section{REFERENCES}

1. Khanfar HS, Bindayna KM, Senok AC, Botta GA. Extended-spectrum beta-lactamases (ESBLs) in Escherichia coli and Klebsiella pneumoniae: trends in the hospital and community settings. J Infect DevCtries. 2009; 3:295-99.DOI:10.3855/jidc.1272. Mendelson G, Hait V, Ben-Israel J, Gronish D, Granot
E, Raz R. Prevalence and risk factors of extendedspectrum beta-lactamase-producing Escherichia coli and Klebsiella pneumoniae in an Israeli long-term care facility. Eur J ClinMicrobiol Infect Dis. 2005; 24:17-22. DOI:10.1007/s10096-004-1264-8 PMID:15660255.

3. Minarini LAR, Gales AC, Palazzo ICV, Darini ALC. Prevalence of Community-Occurring Extended Spectrum $\beta$-Lactamase-Producing Enterobacteriaceae in Brazil. CurrMicrobiol. 2007; 54:335-41. DOI:10.1007/s00284-006-0307-z PMID:17457648.

4. European Centre for Disease Prevention and Control. Systematic review of the effectiveness of infection control measures to prevent the transmission of extended-spectrum beta-lactamase-producing Enterobacteriaceae through cross-border transfer of patients. Stockholm: ECDC. 2014.

5. Paterson DL, Ko WC, Von Gottberg A, Mohapatra S, Casellas JM, Goossens H, Mulazimoglu L, Trenholme G, Klugman KP, Bonomo RA, Rice LB, Wagener MM, Mc Cormack JG, Yu VL. International prospective study of Klebsiella pneumoniae bacteremia: implications of extended-spectrum beta-lactamase production in nosocomialinfections.AnnInternMed.2004;140:26-32. DOI:10.7326/0003-4819-140-1-200401060-00008 PMID:14706969.

6. Queenan AM, Bush K. Carbapenemases: the versatile beta-lactamases. ClinMicrobiol Rev. 2007; 20(3):44058. DOI:10.1128/CMR.00001-07 PMID:17630334.

7. Grundmann H, Glasner C, Albiger B, Aanensen DM, Tomlinson CT, Andrasević AT, et al. Occurrence of carbapenemase-producing Klebsiella pneumoniae and in the European survey of carbapenemaseproducing Enterobacteriaceae (EuSCAPE): a prospective, multinational study. Lancet Infect Dis. 2017;17(2):153-63. DOI:10.1016/S14733099(16)30257-2

8. Peleg AY, Hooper DC. Hospital-acquired infections due to gram negative bacteria. NEngl J Med. 2010; 362:1804-13.DO I: 10.1056 / NEJMra 0904124 PMID:20463340.

9. Guh AY, Limbago BM, Kallen AJ. Epidemiology and prevention of carbapenem-resistant Enterobacteriaceae in the United States. Expert Rev Anti Infect Ther. 2014; 12:565-80.DOI:10.1586/1478 7210.2014.902306 PMID:24666262.

10. Clinical and Laboratory Standards Institute. Performance standards for antimicrobial susceptibility testing; 22nd informational supplement. CLSI document M100-S22. Clinical and Laboratory 
Standards Institute, Wayne, PA.CLSI; 2012.

11. WHQ Guide to Implementation of the WHO Multimodal Health Organization. WHO; 2009a.

12. Boyce JM, Pittet D. Guideline for Hand Hygiene in Health-Care Settings. Recommendations of the Healthcare Infection Control Practices Advisory Committee and the HICPAC/SHEA/APIC/IDSA Hand Hygiene Task Force. Society for Healthcare Epidemiology of America/Association for Professionals in Infection Control/Infectious Diseases Society of America.MMWR Recomm Rep. 2002;51:145.DOI:10.1086/503164 PMID:12515399.

13. Pittet D, HugonnetS, Harbarth S, Mourouga P, Sauvan V, Touveneau S, PernegerTV. Effectiveness of a hospitalwideprogramme to improve compliance with hand hygiene. Infection Control Programme. Lancet.2000; 356: 1307-12.DOI:10.1016/S01406736(00)02814 2

14. Collee JG, Barrie PM, Fraser AG, Simmons A. Mackie and McCartney Practical Medical Microbiology. 14th ed. Edinburgh: Churchill Livingstone: 2007.

15. Clinical Laboratory Standards institute. Performance Standards for Antimicrobial Susceptibility Testing. 27th ed. CLSI supplement M100. Wayne, PA: Clinical and Laboratory Standards Institute; 2017.

16. Clinical Laboratory Standards institute. Current Clinical and Laboratory Standards Institute (CLSI). Criteria for interpretation of susceptibility testing of carbapenems in Enterobacteriaceae. CLSI document M100 S22; 2012.

17. Clinical Laboratory Standards institute. Guidance for control of infections with carbapenem-resistant or carbapenemase producing Enterobacteriaceae in acute care facilities.MMWR Weekly. 2009; 58(10): 256-60.

18. Kumari D. Study on the bacterial isolates from hand swab samples of health care workers and anti-biotic sensitivity pattern, in a tertiary care hospital, Lucknow. Int J Adv Res. 2017; 5(3): 2367-73.DOI:10.21474/ IJAR01/376619.

19. Vedavati BI, Halesh LH. Bacterial flora on hands of nursing staff as a source of health care associated infections at a tertiary care centre. Indian J Microbiol Res. 2019;6(1):30-34.DOI:10.18231/23945478.2019.000720.

20. Lohani B, ThapaM,SharmaL,AdhikariH,Sah AK, Khanal AB, Basnet RB and Aryal M. Predominance of CTX-M Type Extended Spectrum -lactamase
(ESBL) Producers Among Clinical Isolates of Enterobacteriaceae in a Tertiary Care Hospital, Kathmandu, Nepal. The Open Microbiol J.2019; 13:2833.DOI:10.2174/1874285801913010028

21. Nepal K, Pant ND, Neupane B, Belbase A, Baidhya R, Shrestha RK, Lekhak B, Bhatta DR, Jha B. Extended spectrum beta-lactamase and metallo beta-lactamase production among Escherichia coli and Klebsiella pneumoniae isolated from different clinical samples in a tertiary care hospital in Kathmandu, Nepal. Ann Clin Microbiol Antimicrob. 2017; 16:62.DOI:10.1186/ s12941-017-0236-7 PMID:28927454

22. Chaudhary U, Aggarwal R. Extended spectrum $\beta$-lactamases (ESBL) - An emerging threat to clinical therapeutics. Indian J Med Microbiol. 2004;22(2):7580.

23. Chander A, Shrestha CD. Prevalence of extended spectrum beta lactamase producing Escherichia coli and Klebsiella pneumoniae urinary isolates in a tertiary care hospital in Kathmandu, Nepal. BMC Res Notes.2013; 6:487.DOI: 10.1186/1756-0500-6-487 PMID:24274894.

24. Mahaseth SN, Sanjana RK, Jha BK, Pokharel K. Prevalence of Extended Spectrum Beta-Lactamase Producing Escherichia coli and Klebsiella pneumoniae Isolated from Urinary Tract Infected Patients Attending Tertiary Care Hospital, Central Nepal. JCMS Nepal. 2019; 15(3): 211-7. DOI:10.3126/jcmsn. v15i3.2260225.

25. Ibadin EE, Omoregie R, Igbarumah IO, Anogie NA, Ogefere HO. Prevalence of Extended Spectrum $\beta$-Lactamase, AmpC $\beta$-Lactamase and Metallo- $\beta$ Lactamase among Gram negative bacilli recovered from clinical specimens in Benin city, Nigeria. Int J Enteric Pathog. 2017; 5(3): 85-91. DOI:10.15171/ ijep.2017.2026.

26. Bhuyan B, Sargiary P, Nath R. Study of Extended Spectrum Beta Lactamase and Metallo Beta Lactamase Production among Gram Negative Clinical Isolates from a Tertiary Care Hospital, North-East India. Int J Med Res Prof. 2018;4(4):64-68.

27. Metri BC, Jyothi P, Peerapur BV. The prevalence of ESBL among Enterobacteriaceae in a tertiary care hospital of North Karnataka, India.J Clin Diagn Res. 2011; 5:470-5.

28. Pokharel K, Dawadi BR, Bhatta CP, Gupte S, Jha, B. Resistance Pattern of Carbapenem on Enterobacteriaceae. Journal of Nepal Medical Association. 2018; 56(214):931-35.DOI: 10.31729/ 
jnma.400629. Bora A, Sanjana R, Jha BK, Mahaseth SN, Pokharel K. Incidence of metallo-beta-lactamase producing clinical isolates of Escherichia coli and Klebsiella pneumoniae in central Nepal. BMC Research Notes.2014;7:557.DOI:10.1186/1756-0500-7-557 PMID:25146590.

30. Yusuf I, Yahaya S, Qabli S, Algarni S, Gbadamosi. Phenotypic Detection of Extended Spectrum Beta lactamase and Carbapenemase Co-producing Clinical Isolates from Two Tertiary Hospitals in Kano, North West Nigeria. Ethiop J Health Sci. 2017; 27(1):3-10. DOI:10.4314/ejhs.v27i1.2 PMID:28458485. 